\title{
PAHAM QADARIYAH DAN JABARIYAH PADA PELAKU PASAR PELELANGAN IKAN BAJOE KABUPATEN BONE PROPINSI SULAWESI SELATAN
}

\author{
Muhammad Hasbi \\ STAIN Watampone \\ e-mail: muh_hasbi21@yahoo.co.id
}

\begin{abstract}
This article discusses the thoughts of fish auction market in Bajoe on Qadariyah and Jabariyah and the role of Qadariyah and Jabariyah theology. The methodology used for this research is a descriptive method, to explain the problem, events, and any recent phenomenon. In Islamic thoughts, human activities are interpreted in two mainstreams of thoughts. Firstly, the interpretation that human is a free to will, that human activities are created by his self. Secondly, human actions are not created by man, but by God. For this group, a human is not strong enough to do anything, God controls everything. The first stream, in Islamic thought known as Qadariyah, while the second is called Jabariyah. Several people in the community of fish auction market of Bajoe agree on the opinions of Qadariyah and Jabariyah, while some others disagree. Similarly, most of them are affected by Qadariyah and partly influenced by Jabariyah.
\end{abstract}

Artikel ini membahas tentang pandangan masyarakat pelaku pelelangan ikan Bajoe terhadap paham Qadariyah dan Jabariyah serta peran teologinya. Metode penelitian yang digunakan adalah deskriptif untuk menjelaskan masalah, peristiwa dan fenomena yang ada sampai pada masa sekarang. Pada pemikiran Islam, perbuatan manusia diinterpretasikan pada dua paham. Pertama, manusia mempunyai kebebasan dan kekuatan sendiri untuk mewujudkan perbuatanperbuatannya. Kedua, perbuatan manusia bukanlah disebabkan oleh manusia, melainkan Allah. Pada kelompok ini, manusia tidak memiliki kekuatan untuk berbuat sesuatu, Allah mengendalikan semuanya. Paham pertama dikenal dengan Qadariyah, sedangkan paham yang kedua disebut Jabariyah. Beberapa 
orang di pasar pelelangan ikan menyetujui paham Qadariyah dan Jabariyah, sebagian lainnya tidak sependapat. Dari hasil penelitian dapat disimpulkan bahwa sebagian besar dari mereka dipengaruhi oleh paham Qadariyah dan sebagian kecil dipengaruhi oleh paham Jabariyah.

Keywords: Qadariyah, Jabariyah, the fish auction market community

\section{Pendahuluan}

Secara geografis Bajoe terletak $6 \mathrm{~km}$ dari kota Watampone yang didominasi oleh penduduk dengan mata pencaharian sebagai nelayan, pedagang, niaga transportasi dan petani. Dari aktivitas yang heterogen ini ditunjang oleh suatu pemukiman dengan material pendukung, umumnya berasal dari alam dan berdiri di atas perairan laut di sepanjang garis pantai yang permukaan lahannya selalu digenangi air laut pada hampir sepanjang waktu, kecuali pada waktu-waktu surut akibat pengaruh pasang surut permukaan air laut .

Pelelangan ikan Bajoe merupakan pusat perbelanjaan ikan masyarakat Bajoe dan masyarakat kota Watampone. Pelelangan ikan ini masuk dalam wilayah kecamatan kota, yakni Kecamatan Tanete Riattang Timur Kabupatan Bone Sulawesi Selatan. Masyarakat di sekitar pelelangan ikan dan pesisir pantai Bajoe mayoritas beragama Islam dan memiliki potensi keagamaan yang sangat besar dengan bermatapencaharian sebagai nelayan. Penghuni pemukiman masyarakat pesisir pantai Bajoe, mata pencaharian pokoknya menangkap ikan dengan menggunakan perahu layar. Apalagi suku Bajo, suku ini terkenal sebagai suku bangsa pelaut di Indonesia yang telah mengembangkan suatu kebudayaan maritim sejak beberapa abad lamanya sehingga dikenal dengan sebutan "manusia perahu".

Sebagai manusia perahu, mereka mengenal budaya Alloping yaitu pedoman atau aturan membangun perahu. Budaya Alloping inilah yang kemudian berkembang menjadi budaya Appabolang, setelah mereka menetap dalam suatu hunian dan mengelompok menjadi suatu permukiman. Budaya Appabolang itu sendiri adalah faktor-faktor yang menjadi pertimbangan suku Bajo untuk mendirikan rumah tinggalnya. Faktor-faktor tersebut adalah agama/kepercayaan, hubungan sosial, mata pencaharian, pengetahuan, pola hidup, dan lingkungan alam. Fenomena menarik di sini adalah kemampuan rumah tinggal suku Bajo yang tercipta dari hasil budaya Appabolang untuk tetap bertahan dan eksis dalam menghadapi lingkungan alam di wilayah pesisir Bajoe yang sangat keras.

Perairan Bajoe dikenal dengan jenis pasang surut ganda campuran (mixed 
tide, prevailing semidiurnal) yaitu 2 kali pasang dan 2 kali surut dalam sehari. Keadaan ini menjadi tantangan bagi rumah tinggal yang berhubungan langsung dengan laut untuk tetap bertahan dan menyesuaikan diri dengan air pasang dan kelembaban yang ditimbulkannya. Kencangnya angin yang bertiup dari laut maupun dari darat dapat merubah suhu udara menjadi sangat dingin. Curah hujan terjadi sepanjang tahun sehingga sulit menentukan musim hujan atau musim kemarau. Untuk itu harus selalu siap menanti turunnya hujan. Hal-hal seperti inilah yang banyak mendatangkan masalah dan sangat penting diperhatikan untuk mengetahui paham mereka, khususnya paham Qadariyah dan Jabariyah. Untuk itu, ketangguhan rumah tinggal suku Bajo untuk mengatasi pengaruh iklim sehingga kenyamanan terma dalam bangunannya dapat tercapai. Sebagaimana telah diuraikan di atas bahwa sebagai "manusia perahu", mereka melakukan segala aktivitas dan menghabiskan hidupnya di atas perahu.

Ada dua konsep yang berkembang di kalangan muslim yang digunakan menghadapi berbagai masalah yaitu Qadariyah dan Jabariyah. Menurut paham Qadariyah bahwa manusia mempunyai kebebasan dan kekuatan sendiri untuk mewujudkan perbuatan-perbuatannya. Dalam bahasa Inggris, paham Qadariyah ini dikenal dengan nama free will dan free act (Nasution, 1986: 31). Oleh karena itu, paham ini lebih dikenal dengan nama Qadariyah. Nama Qadariyah berasal dari pengertian bahwa manusia mempunyai qudrah atau kekuatan untuk melaksanakan kehendaknya, dan bukan berasal dari pengertian bahwa manusia terpaksa tunduk pada qadar Tuhan. Qadariyah tidak dapat diketahui dengan pasti kapan paham ini timbul dalam sejarah perkembangan teologi Islam. Menurut keterangan ahli-ahli teologi Islam, paham Qadariyah kelihatannya ditimbulkan pertama kali oleh seorang bernama Ma'bad al Jauhani. Ma'bad al Jauhani dan temannya Ghailan al Dimasyqy mengambil paham ini dari seorang Kristen yang masuk Islam di Irak (Amin, 1965: 255).

Ghailan dalam perkembangannya terus menyiarkan paham Qadariyah sampai di Damaskus, tetapi mendapat tantangan dari khalifah Umar Ibnu Abd al Aziz. Setelah Umar wafat ia meneruskan ajarannya. Menurut Ghailan, manusia berkuasa atas perbuatan-perbuatannya, manusia sendirilah yang menentukan perbuatan-perbuatan baik atas kehendak dan kekuasaannya sendiri, dan manusia sendiri pula yang melakukan atau menjauhi perbuatanperbuatan jahat atas kemauan dan dayanya sendiri (Al Gurabi: 33). Dalam paham ini manusia merdeka dalam tingkah lakunya. Ia berbuat baik adalah atas kemauan dan kehendaknya sendiri. Di sini tidak terdapat paham yang 
mengatakan bahwa nasib manusia telah ditentukan terlebih dahulu dan manusia dalam perbuatan-perbuatannya hanya bertindak menurut nasib yang telah ditentukan semenjak zaman azali (Hasbi, 2010: 52).

Kaum Jabariyah berpendapat sebaliknya, manusia tidak mempunyai kemerdekaan dalam menentukan kehendak dan perbuatannya. Manusia dalam hal ini terikat pada kehendak mutlak Tuhan. Dalam bahasa Inggris, paham ini disebut predestination atau fatalism. Oleh karena itu, paham ini lebih dikenal dengan nama Jabariyah. Nama Jabariyah berasal dari kata jabara yang mengandung arti memaksa. Memang dalam aliran ini terdapat paham bahwa manusia mengerjakan perbuatannya dalam keadaan terpaksa. Perbuatan-perbuatan manusia telah ditentukan dari semula oleh qada dan qadar Tuhan.

Paham Jabariyah diperkenalkan pertama kali dalam sejarah teologi Islam oleh Al Ja'd Ibnuu Dirham (Mulyono dan Bashori, 2010:140). Tetapi yang menyiarkannya adalah Jahm Ibnu Safwan dari Khurasan. Perlu diketahui bahwa Jahm yang terdapat dalam aliran Jabariyah ini sama dengan Jahm yang mendirikan golongan Al Jahmiyah dalam kalangan Murjiah (Amin, 1965: 286). Paham yang dibawa Jahm adalah lawan ekstrim dari paham yang diajukan Ma'bad dan Ghailan. Manusia, menurut Jahm tidak mempunyai kekuasaan untuk berbuat apa-apa, manusia tidak mempunyai daya, tidak mempunyai kehendak sendiri dan tidak mempunyai pilihan, manusia dalam pebuatan-perbuatannya adalah dipaksa dengan tidak ada kekuasaan, kemauan dan pilihan baginya.

Perbuatan-perbuatan yang diciptakan Tuhan di dalam diri manusia tak ubahnya dengan gerak yang diciptakan Tuhan dalam benda-benda mati. Oleh karena itu, manusia dikatakan berbuat bukan dalam arti sebenarnya, tetapi dalam arti majazi. Segala perbuatan manusia merupakan perbuatan yang dipaksakan atas dirinya termasuk perbuatan-perbuatan seperti mengerjakan kewajiban, menerima pahala dan menerima siksaan (Al Syahrastaniy: 87). Menurut paham ekstrim ini, segala perbuatan manusia bukanlah merupakan perbuatan yang timbul dari kemauannya sendiri, tetapi perbuatan yang dipaksakan atas dirinya. Manusia dalam paham ini hanya merupakan wayang yang digerakkan. Demikian pula, manusia bergerak, berusaha dan berbuat karena digerakkan Tuhan. Tanpa gerak dan usaha dari Tuhan manusia tidak bisa berbuat apa-apa.

Paham Jabariyah yang moderat sebagaimana yang disebutkan Al Syahrastani 
yaitu paham yang dibawa oleh Al-Husain Ibnu Muhammad al-Najjar. Menurut Al-Najjar, Tuhanlah yang menciptakan perbuatan-perbuatan manusia, baik perbuatan jahat maupun perbuatan baik, tetapi manusia mempunyai bagian dalam perwujudan perbuatan-perbuatan itu. Tenaga yang diciptakan dalam diri manusia mempunyai efek untuk mewujudkan perbuatan-perbuatannya. Dan inilah yang dimaksud dengan kasb atau acquisition (Al Syahrastaniy: 89). Paham yang sama diberikan oleh Dirar Ibnuu 'Amr, ia katakan bahwa perbuatanperbuatan manusia pada hakekatnya diciptakan Tuhan. Pengaruh Qadariyah dan Jabariyah tersebut akhirnya berkembang pula sampai ke Indonesia.

Sebagaimana telah diuraikan di atas bahwa sebagai "manusia perahu", suku Bajo melakukan segala aktivitasnya di atas perahu. Sejalan dengan bertambahnya waktu "manusia perahu" ini menetap dalam suatu hunian dan mengelompok membentuk suatu pemukiman. Namun, budaya laut mereka masih mempengaruhi hidupnya sampai sekarang. Hal inilah yang mendorong Pemerintah Daerah Kabupaten Bone untuk membangun pelelangan ikan di Bajoe yang dibangun pada masa pemerintahan $\mathrm{H}$. Andi M. Idris Galigo, SH. pada tahun 2011. Pelelangan Ikan ini semakin ramai karena tempatnya sangat strategis. Dalam tulisan ini masalah yang diangkat bagaimana pandangan masyarakat pelaku pasar pelelangan ikan Bajoe tentang Qadariyah dan Jabariyah serta peran teologinya.

\section{Metode Penelitian}

Penelitian ini menggunakan metode deskriptif yang bertujuan untuk mendeskripsikan suatu masalah, kejadian, fenomena yang ada sampai pada masa sekarang. Atau dengan kata lain metode deskriptif dilakukan untuk menjawab persoalan-persoalan tentang fenomena yang ada dan berlaku sampai sekarang.

Populasi penelitian meliputi populasi utama dan populasi penunjang. Pada populasi utama meliputi seluruh pelaku pasar Pelelangan Ikan Bajoe Kecamatan Tanete Riattang Timur Kabupaten Bone. Sedangkan sampel penelitian dipilih dari populasi penelitian tersebut. Sampel penelitian utama menggunakan cluster random sampling dengan mengacu pada pertimbangan jangkauan tempat penelitian, yaitu seluruh seluruh pelaku pasar pelelangan ikan pesisir pantai Bajoe Kecamatan Tanete Riattang Timur Kabupaten Bone. Sedangkan sampel penunjang meliputi sampel yang digunakan di pasar Pelelangan Ikan Bajoe yang dianggap refresentatif untuk diwawancarai pandangannya tentang paham Qadariyah dan Jabariyah dan pengaruh Qadariyah dan Jabariyah terhadap 
mereka. Berdasar pertimbangan tersebut diharapkan dapat memberikan data dan informasi yang akurat atas segala yang dibutuhkan.

Pengumpulan data dilakukan 3 (tiga) teknik. Pertama, observasi yaitu melakukan pengamatan dan pencatatan yang sistematis terhadap pelaku pasar pelelangan ikan Bajoe. Pencatatan dapat dibagi menjadi dua yaitu deskriptif dan reflektif. Catatan deskriptif menyajikan lebih rinci, mengutip pernyataan orang, bukan meringkaskan apa yang. Sedangkan catatan reflektif lebih mengetengahkan kerangka pikiran, ide dan perhatian dari peneliti, dan lebih menampilkan komentar peneliti. Kedua, wawancara dapat difungsikan dalam dua cara, yaitu sebagai metode utama penelitian, dan sebagai pelengkap dari metode observasi. Ketiga, angket yaitu dengan melakukan pengumpulan data dalam bentuk pertanyaan yang diberikan kepada seluruh anggota sampel dengan menggunakan sistem perwakilan pada pelaku pasar pelelangan ikan Bajoe.

\section{Profil Masyarakat Pesisir Pantai Bajoe Kabupaten Bone}

Nenek moyang bangsa Indonesia dikenal sebagai pelaut ulung. Julukan itu masih melekat pada keseharian masyarakat pesisir pantai Bajoe, khususnya suku Bajo. Sejak ratusan tahun lampau, warga Bajo memang hidup di atas laut. Dengan hanya menggunakan perahu, mereka piawai mengarungi gelombang demi gelombang tanpa mengenal lelah. Hingga akhirnya, para pendahulu suku Bajo membangun pemukiman di permukaan samudera. Menurut pandangan masyarakat suku Bajo, laut adalah segalanya. Mereka memandang laut sebagai satu-satunya sumber penghidupan. Sejak ratusan tahun lampau, masyarakat suku Bajo memandang laut sebagai lahan mencari nafkah, tempat tinggal, serta beranak-pinak. Masyarakat Bajo adalah nelayan tradisional yang mampu memanfaatkan kekayaan laut untuk bertahan hidup. Pada umumnya, masyarakat suku Bajo tersebar dan hidup di perairan Indonesia dengan mata pencaharian sebagai nelayan. Hampir di seluruh wilayah perairan di Indonesia mengenal adanya masyarakat suku Bajo yang hidup dan bertempat tinggal di daerah pesisir laut. Lingkungan masyarakat suku Bajo dari dulu hingga sekarang tidak pernah lepas dari laut.

Masyarakat nelayan adalah masyarakat yang hidup, tumbuh dan berkembang di kawasan pesisir, yakni suatu kawasan transisi antara wilayah darat dan laut. Sebagai suatu sistem, masyarakat nelayan terdiri atas kategorikategori sosial yang membentuk kesatuan sosial. Mereka juga memiliki sistem nilai dan simbol-simbol kebudayaan sebagai referensi perilaku mereka sehari- 
hari. Faktor kebudayaan inilah yang menjadi pembeda antara masyarakat nelayan dengan kelompok sosial lainnya. Sebagian besar masyarakat pesisir, baik langsung maupun tidak langsung telah menggantungkan kelangsungan hidupnya dari mengelola potensi sumber daya kelautan.

Masyarakat nelayan menghadapi banyak ragam masalah, antara lain : 1) kemiskinan, kesenjangan sosial dan tekanan-tekanan ekonomi yang datang setiap saat; 2) keterbatasan akses modal, teknologi dan pasar sehingga mempengaruhi dinamika usaha; 3) kelemahan fungsi kelembagaan sosial ekonomi yang ada; 4) kualitas sumber daya manusia (SDM) yang rendah sebagai akibat keterbatasan akses pendidikan, kesehatan dan pelayanan publik; 5) degradasi sumberdaya lingkungan, baik di kawasan pesisir, laut maupun di pulau-pulau kecil; dan 6) belum kuatnya kebijakan yang berorientasi pada kemaritiman sebagai pilar utama pembangunan nasional. Masyarakat pesisir mempunyai keunikan tersendiri.

Masyarakat pesisir mampu menampilkan suatu perbedaan bentuk dan tradisi yang mencerminkan keanekaragaman daerah dan kekayaan warisan sejarah. Rumah tradisional suku-suku yang mendiami kawasan pesisir pantai di seluruh nusantara. Bentuk-bentuk unik yang ditampilkan merupakan cerminan identitas lokal yang memperkaya khasanah budaya Nusantara. Keanekaragaman rumah tradisional yang ada di Nusantara dalam nuansa seni yang tinggi.

Terbentuknya permukiman komunitas suku Bugis dan suku Bajo di pesisir pantai Bajoe di sekitar pelelangan ikan Bajoe dilatarbelakangi oleh sebagian besar masyarakatnya yang mempunyai sumber mata pencaharian sebagai nelayan. Mereka membentuk permukiman kampung nelayan untuk memudahkan aksesibilitas terhadap kegiatan sehari-hari sebagai nelayan, mulai dari penangkapan ikan ataupun hasil-hasil laut lainnya sampai pada pemasaran.

\section{Pandangan Masyarakat Pelaku Pasar Pelelangan Ikan Bajoe tentang Qadariyah dan Jabariyah}

Teologi Islam merupakan suatu kenyataan sejarah yang tidak dapat disangkal keberadaannya. Dalam ranah pemikiran Islam, perbuatan manusia diinterpretasikan oleh dua aliran yang paradoks. Pertama, ada yang memandangnya sebagai kehendak bebas manusia (Qadariyah), bahwa perbuatan-perbuatan manusia itu adalah diciptakan manusia sendiri. Manusialah yang berkehendak. Apa yang dia inginkan, dia bisa lakukan. Sebaliknya, yang tidak diinginkan, 
dia bisa saja untuk tidak melakukannya. Kedua, bagi kelompok ini perbuatan manusia itu bukan diciptakan oleh manusia (Jabariyah), melainkan oleh Allah SWT. Bagi kelompok ini, manusia tidak bisa berbuat apa-apa, manusia tidak memiliki kekuatan untuk melakukan perbuatan. Manusia hanyalah dikendalikan Allah SWT. Aliran pertama ini, dalam pemikiran Islam dikenal dengan sebutan Qadariyah. Sementara yang kedua disebut Jabariyah. Konsepsi tentang perbuatan manusia pun sering dijadikan hal dalam menentukan maju dan mundurnya, berkembang dan terbelakangnya keadaan umat Islam sekarang. Bagi kalangan liberalis, paham Jabariyah yang menurut mereka kemudian diformulasikan oleh Asy'ari dan dianut oleh Ahlusunnah waljama'ah. Bagi mereka, jika umat Islam ingin maju, Qadariyah atau Muktazilah yang harus dianut atau dijadikan worldview untuk mengembalikan kemajuan peradaban Islam, seperti yang dikatakan oleh Abd. Rahman. Menurutnya manusia harus berusaha semaksimal mungkin untuk meraih kesuksesan dalam berbisnis dengan punya semangat "kalau orang bisa kenapa kita tidak bisa" dan tidak boleh terlebih dahulu tunduk kepada takdir karena tidak ada manusia yang mengetahui takdirnya, karena itu adalah rahasia Tuhan (Wawancara, 1 September 2014).

Hal ini berbeda dengan Malla yang mengatakan bahwa manusia tidak memiliki daya dan upaya untuk menentukan nasibnya, semuanya tergantung pada takdir Tuhan (Wawancara, 5 September 2013). Sedangkan Samsuddin berpendapat sebaliknya, tergantung sejauh mana usaha manusia itu untuk menentukan perjalanan hidupnya, namun demikian manusia dituntut untuk mempertanggungjawabkan segala apa yang telah ia perbuat. Samsuddin secara jujur mengatakan bahwa istilah Qadariyah dan Jabariyah betul-betul tidak dipahami dan bahkan baru pertama kali mendengar istilah tersebut. Akan tetapi, ia berusaha berbisnis menjual ikan di pelelangan ikan Bajoe atas kemauan dan kehendaknya sendiri (Wawancara, 3 September 2013). Demikian pula, Samsu tidak mengenal Qadariyah dan Jabariyah. Namun, manusia mampu mewujudkan perbuatan-perbuatannya untuk berusaha dan berbisnis (Wawancara, 5 September 2013). Manusia mempunyai akal sehingga mengetahui perbuatan baik maupun perbuatan buruk. Karenanya, manusia berhak mendapatkan upah dan siksaan terhadap apa yang dilakukannya di akhirat nanti. Tuhan itu bersih dari penyandaran keburukan dan kezaliman, dari kekufuran dan kemaksiatan. Seandainya kezaliman itu diciptakan Tuhan, berarti Dia zalim. Menurut Samsu, manusia diberi kebebasan untuk berbuat, kehendak berbuat adalah kehendak manusia. 
Menurut peneliti, dari pemaparan di atas, tidak dijelaskan apakah daya yang dipakai untuk mewujudkan perbuatan itu adalah juga daya manusia sendiri, bukan daya Tuhan. Dalam hubungan ini, perlu kiranya ditegaskan bahwa untuk terwujudnya perbuatan, harus ada kemauan atau kehendak dan daya untuk melaksanakan kehendak itu dan kemudian barulah terwujud perbuatan.

Berbeda dengan Mondeng, kita ini sebagai manusia adalah makhluk yang lemah yang diciptakan oleh Allah SWT. Manusia dalam kelemahannya banyak bergantung kepada kehendak dan kekuasaan Tuhan (Wawancara, 2 September 2013). Hal ini senada dengan pandangan Al-Asy'ari, seperti yang diungkapkan oleh Harun Nasution. Dalam hal ini, Mondeng berpandangan bahwa manusia mempunyai daya sendiri. Akan tetapi, daya manusia itu tidak mempunyai arti apa-apa tanpa ditopang oleh daya Tuhan atau kemauan Tuhan (Wawancara, 2 September 2013). Untuk terwujudnya perbuatan perlu ada dua daya, yaitu daya Tuhan dan daya manusia. Tetapi yang berpengaruh dan yang efektif pada akhirnya dalam perwujudan perbuatan ialah daya Tuhan.

Menurut pengamatan peneliti, para responden pada dasarnya ingin membela Allah SWT. Bagi mereka, Allah SWT itu adil. Dia tidak mungkin dinisbatkan dengan kejahatan dan kezaliman, yang keduanya itu terdapat dalam perbuatan manusia. Sehingga, bagi mereka perbuatan zalim, buruk, jahat dan juga perbuatan baik itu merupakan perbuatan murni manusia. Namun tanpa disadari dengan teologinya ini mereka menafikan kekuasaan dan kehendak mutlak Allah SWT. Di lain sisi, dengan penekanan yang berbeda, bahkan mungkin bisa dikatakan bertentangan, Mondeng menganggap bahwa Tuhan itu berkuasa dan berkehendak secara mutlak. Sedangkan menurut Al-Asy'ari bahwa Allah bisa saja melakukan apa saja yang dikehendaki-Nya. Dia bisa saja memasukkan orang yang suka berbuat maksiat ke dalam surga. Karena dari awal, surga dan neraka sudah ditetapkan penghuninya.

Menurut Senabe perbuatan manusia adalah juga ciptaan Tuhan. Manusia sama sekali tidak memiliki kekuatan. Manusia tidak dapat berbuat tanpa dibarengi dengan perbuatan Tuhan. Dalam arti ada perbuatan manusia dan ada perbuatan Tuhan (Wawancara, 26 September 2013). Sungguhpun demikian, menurut Hamid, bahwa segala kemauan dan kehendak manusia adalah kemauan dan kehendak Tuhan. Perbuatan manusia mempunyai wujud atas kehendak Tuhan dan bukan atas kehendak manusia sendiri (Wawancara, 22 September 2013). 
Menurut peneliti, pendapat Senabe memiliki kemiripan dengan Maturidiah. Bagi Maturidiah, perbuatan itu ada dua, yaitu: pertama, perbuatan Tuhan dan kedua, perbuatan manusia. Perbuatan Tuhan mengambil bentuk penciptaan daya dalam diri manusia dan pemakaian daya itu sendiri merupakan perbuatan manusia. Daya diciptakan bersama-sama dengan perbuatan. Perbuatan manusia, bagi Maturidiah adalah perbuatan manusia dalam arti sebenarnya dan bukan dalam arti kiasan. Pemberian upah dan hukuman didasarkan atas pemakaian daya yang diciptakan. Dengan demikian, manusia diberi hukaman atas kesalahan pemakaian daya dan diberi upah atas pemakaian yang benar dari daya.

Pendapat Hamid tersebut di atas sama dengan pendapat aliran Maturidiah, baik golongan Samarkand maupun Bukhara, kemauan manusia adalah sebenarnya kemauan Tuhan, ini mengandung arti paksaan atau fatalism. Tetapi sebagai pengikut Abu Hanifah, Maturidiah membawa ke dalam hal ini paham masyi'ah atau kemauan dan ridha atau kerelaan. Manusia melakukan segala perbuatan baik dan buruk atas kehendak Tuhan, tetapi tidak selamanya dengan kerelaan Tuhan. Tuhan tidak suka manusia berbuat jahat. Tegasnya, manusia berbuat baik atas kehendak Tuhan; sebaliknya memang benar jika manusia berbuat buruk atas kehendak Tuhan tetapi tidak atas kerelaan Tuhan.

\section{Peran Teologi Qadariyah dan Jabariyah terhadap Masyarakat Pelaku Pasar Pelelangan Ikan Bajoe}

Teologi takdir adalah sangat penting karena dapat menjadi salah satu faktor utama yang menyebabkan maju dan mundurnya umat Islam. Ada paham takdir yang dapat menyebabkan umat Islam mundur dan lemah; sebaliknya ada pula paham takdir yang dapat mendorong umat Islam kepada kemajuan dan kekuatan. Dua pemikiran mengenai takdir tersebut adalah paham Jabariyah (predestination) dan paham Qadariyah (free will).

Oleh karena itu, Samsuddin mengatakan bahwa deegaga missengngi garisi warekkenna, artinya tidak ada satu pun manusia mengetahui takdirnya. Olehnya itu, manusia wajib berikhtiar dalam arti berusaha semaksimal mungkin untuk memperoleh kebahagian dan kesenangan di dunia. Demikian pula, untuk memdapatkan kebahagiaan di akhirat (Wawancara, 5 September 2013). Dalam hal ini, berbeda dengan pandangan Malla, walaupun kita berusaha banting tulang untuk mencari dan mendapatkan kebahagiaan dan kesenangan dunia, tapi kalau memang Tuhan takdirkan menjadi orang miskin maka manusia itu akan menjadi miskin (Wawancara, 28 September 2013). 
Mengamati kedua pandangan tersebut, terlihat jika pandangan Samsuddin merupakan paham Qadariyah sedangkan Malla berpaham Jabariyah. Menurut paham ini, takdir Tuhan adalah ketentuan Tuhan bagi mahluk-Nya. Takdir ini menjelma dalam bentuk sifat-sifat alam atau hukum sebab akibat yang pasti berlaku. Manusia diberi kebebasan dalam kemauan dan perbuatan, diberi tanggung jawab agar manusia dapat diuji apakah beriman, beramal saleh atau sebaliknya. Dengan paham ini, manusia diberi landasan untuk bekerja keras, bekerja semaksimal kemampuan dan bertanggung jawab demi dunia dan akhirat. Ada juga mengambil sikap tengah antara Jabariyah dan Qadariyah, yang disebut paham "kasab". Namun, dalam sejarah teologi Islam, hanya membagi paham takdir kepada dua paham yang disebutkan di atas.

Menurut Jufri bahwa Tuhan itu mempunyai sifat (Wawancara, 28 September 2013). Berbeda dengan kaum Muktazilah, menurut Muktazilah bahwa Tuhan itu tidak mempunyai sifat. Al Asy'ari berpendapat bahwa Tuhan mempunyai sifat. Mustahil Tuhan sendiri merupakan pengetahuan (' $\mathrm{Ilm}$ ), yang benar Tuhan itu mengetahui (Alim). Tuhan mengetahui dengan pengetahuan-Nya, bukanlah dengan Zat-Nya.

Demikian pula, apakah Tuhan dapat dilihat di akhirat atau tidak? Menurut Mondeng (Wawancara, 2 September 2013) dan Saide (Wawancara, 21 September 2013), bahwa Tuhan dapat dilihat di akhirat nanti, sebagaimana pemahaman mereka. Dalam hal ini, menurut pengamatan peneliti pengaruh Al-Asy'ari terhadap pemikiran tersebut tidak dapat dipungkiri pemikiran AlAsy'ari tentang melihat Tuhan, bahwa Tuhan dapat dilihat di akhirat. Kata Al-Asy'ari, hanyalah yang tak punya wujud yang tidak dapat dilihat. Setiap wujud mesti dapat dilihat, Tuhan berwujud, dan oleh karena itu dapat dilihat. Argumen al Quran yang diajukannya antara lain, "Wajah-wajah yang ketika itu berseri-seri memandang kepada Allah” (QS al Qiyamah: 22-23).

Terkait dengan keadilan Tuhan, menurut Midang bahwa Allah adalah adil dan wajib berterima kasih kepada-Nya, meyakini bahwa Allah adalah Mahaadil. Keadilan diartikannya menempatkan sesuatu pada tempat yang sebenarnya (Wawancara, 4 September 2013). Hj. Cahe mengatakan bahwa tidak mungkin Allah memasukkan seluruh manusia ke dalam neraka atau memasukkan seluruh manusia ke dalam surga. Tuhan itu adil kalau Dia memasukkan orang kafir ke neraka dan memasukkan orang mukmin ke dalam surga. Demikian pula, Samsuddin mengatakan bahwa tidak mungkin Tuhan akan memasukkan orang mukmin ke dalam neraka atau memasukkan orang kafir ke dalam surga. Neraka itu dipersiapkan untuk orang kafir dan surga 
adalah tempatnya orang-orang yang beriman (Wawancara, 5 September 2013). Menurut Jufri, tidak mungkin Allah menganiaya seluruh umat manusia, baik di dunia atau di akhirat (Wawancara, 28 September 2013).

Manusia sebagai makhluk yang lemah dan tidak dapat berbuat apa-apa tanpa kemauan dan kehendak Allah. Manusia dalam kelemahannya banyak tergantung kepada kehendak dan kekuasaan Tuhan (Wawancara dengan Hamid, 22 September 2013). Akal manusia, menurut Senabe, mempunyai daya yang lemah, akibatnya menjadikan manusia kurang mempunyai ruang gerak karena terikat pada dogma-dogma. Dengan demikian, sangat sulit untuk dapat mengikuti dan mentolerir perubahan dan perkembangan yang terjadi dalam masyarakat modern, seperti yang terjadi pada masyarakat di Bajoe. Paham Jabariyah yang berkembang dalam masyarakat pelelangan ikan Bajoe, seperti rezeki, jodoh dan maut adalah di tangan Tuhan telah menjadikan manusia enggan merubah nasibnya sendiri dan merubah struktur masyarakat. Manusia selalu mempersalahkan takdir atas kemiskinan, kebodohan, dan ketertinggalan karena minimnya pendidikan sehingga sulit mengikuti perkembangan zaman (Wawancara, 26 September 2013).

Berbeda dengan Qadariyah (free will) di pasar pelelangan ikan Bajoe sebagaimana diungkapkan oleh Samsuddin dan Jufri, manusia dipandang mempunyai daya yang besar dan bebas untuk berbuat terlebih jika mau berusaha atau mau berbisnis. Kaum Qadariyah adalah kaum yang memandang perbuatan-perbuatan mereka diwujudkan oleh daya mereka sendiri dan bukan oleh Tuhan. Manusialah yang menciptakan perbuatan-perbuatannya, manusia berbuat baik dan buruk, patuh dan tidak patuh kepada Tuhan atas kehendak dan kemauannya sendiri. Dan daya (al istita'ah) untuk mewujudkan kehendak itu telah terdapat dalam diri manusia sebelum adanya perbuatan.

Demikian pula, menurut Jamil bahwa manusia dalam melakukan perbuatan tidak bisa terlepas dari dua perbuatan, yakni perbuatan manusia itu sendiri dan perbuatan Tuhan. Dalam perbuatan-perbuatan itu terdapat dua unsur, penggerak yang mewujudkan gerak dan badan yang bergerak. Penggerak yaitu yaitu pembuat gerak yang sebenarnya (al fa'il laha 'ala haqiqatiha) adalah Tuhan dan yang bergerak adalah manusia. Bahwa manusia adalah tempat berlakunya perbuatan Tuhan ditegaskan sebagaimana ditegaskan oleh Jamil. Mengenai daya untuk mewujudkan perbuatan-perbuatan, Jamil berpendapat bahwa daya berasal dari manusia dan dari Tuhan. Artinya ada daya Tuhan atau kemauan Tuhan dan ada daya manusia, karena diri manusia dalam menghendaki sesuatu terkadang berhasil dan terkadang tidak berhasil. Daya 
tidak terwujud sebelum adanya perbuatan; daya ada bersama-sama dengan adanya perbuatan dan daya itu ada hanya untuk perbuatan manusia dan perbuatan Tuhan. Daya manusia tidaklah efektif kalau tidak disokong oleh daya Tuhan (Wawancara, 27 September 2013).

Perbuatan yang terletak di dalam lingkungan kekuasaan daya yang diciptakan dan diwujudkan dengan perantaraan daya yang diciptakan. Ini mengandung arti bahwa daya manusia turut serta dalam pewujudan perbuatan. Oleh karena itu manusia dalam hal ini tidaklah seluruhnya bersifat pasif, sebagaimana halnya dengan manusia dalam paham Jabariyah. Tetapi di sini tidak menegaskan lebih lanjut apakah ikut sertanya daya manusia dalam pewujudan perbuatannya bersifat efektif atau bersifat tidak efektif.

Mengenai soal kehendak dalam paham Jabariyah, tentang upah dan hukuman mengandung arti bahwa kemauan manusialah yang menentukan pemakaian daya, baik untuk kebaikan maupun untuk kejahatan. Karena salah atau benarnya pilihan dalam memakai daya, maka manusia diberi hukuman atau upah. Manusia tentu tidak dapat mengadakan pilihan jika ia tidak bebas dan berada di bawah paksaan daya yang lebih kuat dari dirinya. Sesungguhnya yang demikian, di dalam kemauan manusia sebenarnya adalah kemauan Tuhan. Ini berarti bahwa perbuatan manusia mempunyai wujud atas kehendak Tuhan dan bukan atas kehendak manusia. Dan ini selanjutnya mengandung arti paksaan atau fatalism. Manusia melakukan segala perbuatan baik dan buruk atas kehendak Tuhan, tetapi tidak selamanya dengan kerelaan Tuhan. Tuhan tidak suka manusia berbuat jahat.

Jadi kehendak di sini bukanlah kebebasan untuk berbuat sesuatu yang tidak dikehendaki Tuhan, tetapi kebebasan untuk berbuat sesuatu yang tidak disukai Tuhan. Dengan perkataan lain kebebasan kehendak manusia hanya merupakan kebebasan dalam memilih antara apa yang disukai dan apa yang tidak disukai. Jelas bahwa kebebasan serupa ini lebih kecil dari kebebasan dalam menentukan kehendak yang terdapat dalam paham Qadariyah.

Perbedaan lain yang terdapat antara paham Jabariyah dengan paham Qadariyah ialah bahwa daya untuk berbuat diciptakan tidak sebelumnya, tetapi bersama-sama dengan perbuatan yang bersangkutan. Daya yang demikian kelihatannya lebih kecil dari daya yang ada dalam paham Qadariyah. Oleh karena itu, manusia dalam paham Jabariyah tidak sebebas manusia dalam paham Qadariyah.

Adapun Jabariyah dalam pandangan Maturidiah golongan Bukhara, maka bagi mereka kehendak berbuat adalah sama dengan kehendak yang terdapat 
dalam paham golongan Samarkand. Mereka juga mengikuti paham kehendak dan kerelaan hati Tuhan. Kebebasan kehendak bagi mereka hanyalah juga kebebasan untuk berbuat tidak dengan kerelaan hati Tuhan. Daya juga sama, yaitu daya diciptakan bersama-sama dengan perbuatan. Namun demikian, kebebasan manusia dalam paham ini, kalaupun ada kecil sekali. Perbuatan manusia hanyalah melakukan perbuatan yang telah diciptakan Tuhan.

Golongan ini juga berpendapat bahwa untuk pewujudan perbuatan perlu ada dua daya. Manusia tidak mempunyai daya untuk menciptakan. Daya yang ada pada manusia bisa untuk melakukan perbuatan. Hanya Tuhan yang dapat mencipta dan dalam ciptaan-Nya termasuk perbuatan manusia. Dengan demikian manusia hanya dapat melakukan perbuatan yang telah diciptakan Tuhan baginya.

Menurut peneliti kebebasan manusia tidaklah mutlak. Kebebasan dan kekuasaan manusia dibatasi oleh hal-hal yang tak dapat dikuasai oleh manusia sendiri. Sebagaimana manusia datang ke dunia ini bukanlah atas kemauan dan kekuasaannya. Demikian pula menjauhi maut, tiap orang pada dasarnya ingin terus hidup dan tidak ingin mati, tetapi bagaimana pun sekarang atau besok kematian datang juga.

Kebebasan dan kekuasaan manusia, sebenarnya dibatasi oleh hukum alam. Pertama-tama manusia tersusun antara lain dari materi. Materi adalah terbatas, dan mau tak mau sesuai dengan unsur materinya, bersifat terbatas. Manusia hidup dengan dilingkupi oleh hukum-hukum alam yang diciptakan Tuhan. Hukum alam ini tak dapat diubah oleh manusia. Munusia harus tunduk kepada hukum alam itu. Api, nalurinya ialah membakar. Manusia tak dapat merubah naluri itu. Yang dapat dilakukan oleh manusia ialah membuat atau menyusun sesuatu yang tak dapat dimakan api.

Di lihat dari sudut pandangan Qadariyah, sebenarnya bukan api yang tak membakar, tetapi tubuh tertentu itulah yang tak dapat dibakar api. Tak dapat dibakar api, melalui proses tertentu yang merupakan suatu hukum alam pula, yaitu melalui latihan-latihan tertentu. Siapa yang sanggup menjalankan latihan-latihan tersebut, umpamanya kaum fakir yang dikenal di India, kakinya tak dibakar oleh api. Dengan kemajuan ilmu pengetahuan manusia dapat pula menyusun suatu zat yang tak dapat dibakar oleh api, misalnya asbestos. Sebagaimana dengan halnya dengan tubuh manusia tadi, api tetap mempunyai naluri membakar, tetapi asbestos mempunyai naluri tahan api. Oleh karena itu asbestos tak dapat dibakar oleh api. 
Kebebasan dan kekuasaan manusia sebenarnya terbatas dan terikat pada hukum alam. Kebebasan manusia sebenarnya, hanyalah memilih hukum alam mana yang akan ditempuh dan diturutinya. Hal ini perlu ditegaskan, karena paham Qadariyah bisa disalahartikan mengandung paham bahwa manusia adalah bebas sebebas-bebasnya dan dapat melawan kehendak dan kekuasaan Tuhan. Hukum alam pada hakekatnya merupakan kehendak dan kekuasaan Tuhan yang tak dapat dilawan dan ditentang manusia.

\section{Simpulan}

Dari paparan di atas dapat dipahami pandangan masyarakat pelaku Pasar Pelelangan Ikan Bajoe tentang Qadariyah dan Jabariyah dan peran teologi Qadariyah dan Jabariyah terhadap pelaku Pasar Pelelangan Ikan Bajoe Kecamatan Tanete Riattang Timur Kabupaten Bone Propinsi Sulawesi Selatan. Manusia adalah makhluk yang lemah yang diciptakan oleh Allah SWT. Manusia dalam kelemahannya banyak bergantung kepada kehendak dan kekuasaan Tuhan dalam arti manusia tidak dapat menentukan perbuatannya sebagaimana disebut dengan Jabariyah. Hal tersebut berbeda dengan Qadariyah bahwa manusia diberi kebebasan untuk berbuat dan berusaha. Manusia diberi kebebasan untuk menentukan perbuatannya.

Masyarakat pelaku Pasar Pelelangan Ikan Bajoe sebagian besar terpengaruh dengan paham Qadariyah dan sebagian lainnya dipengaruhi oleh paham Jabariyah. Teologi Qadariyah dan Jabariyah menjadi salah satu penyebab utama maju mundurnya umat Islam pada pelaku Pasar Pelelangan Ikan Bajoe. Ada paham yang mendorong umat Islam maju dan berkembang sesuai dengan perkembangan zaman dan ada juga paham yang dapat menyebabkan umat Islam menjadi lemah dan mundurnya umat Islam.

\section{Daftar Pustaka}

Al Ghurabiy, Ali Mustafa. t.th. Tarikh al Firaq al Islamiyyah, Kairo: t.p.

Al Syahrastaniy, Muhammad 'Abd. Al Karim Ibnu Abiy Bakar Ahmad. t.th. Al Milal wa al Nihal, Kairo: Dar al Fikr.

Amin, Ahmad. 1965. Fajr al Islam. Kairo: al Nahdah.

Hans Wehr. 1980. A Dictionary of Modern Written Arabic, Mu'jam al Lugah al Arabiyah al Mua' shirah, Cet III. Bairut: Libanon: Librairie du liban.

Hasbi, Muhammad. 2010. Ilmu Kalam. Yogyakarta: Mitra Cendekia. 
Mulyono dan Bashori. 2010. Studi Ilmu Tauhid/Kalam. Malang: UIN-Maliki Press.

Munawwir, Ahmad Warson. 1984. Kamus Arab Iindonesia. Yogyakarta: Ponpes al Munawwir.

Nasution, Harun. 1986. Teologi Islam Aliran-aliran Sejarah Analisa Perbandingan, Cet. V. Jakarta: UI Press.

Nasution, Harun. 2002. Teologi Islam. Jakarta: UI-Press.

Van Hoeve. 1982. Ensiklopedi indonesia, Jilid III. Jakarta: Icgtiar Baru.

Zaini, Hasan, 1997. Tafsir Tematik Ayat-Ayat Kalam Tafsir al Maraghi, Cet. I. Jakarta: Pedoman Ilmu Jaya.

el Harakah Vol.17 No.1 Tahun 2015 